\title{
PREFACE
}

\section{On Taking Stock}

\section{Dear Chava,}

Karl Barth once wrote that every autobiography is perforce a dubious enterprise. This, he explained, is because the underlying assumption of autobiographical writings is that "a chair exists in which a man can sit down and contemplate his own life, to compare its phases, to survey its development, and to penetrate its meanings." To be sure, he added, every man can and ought to take stock of himself. But he cannot survey himself "even in the present moment, any more than in the whole of his past."

How true. But you, my friend, take things much more easily. "Start right at this point in time," you say with that peculiar finality of tone that is all yours. You are, though, perhaps right. A work of autobiography can be written in any one of a hundred different ways, and my question as to where to start telling this rather partial, very inadequate tale was at best rhetorical, at worst evasive.

"Here and now," you say. But which of the "heres" and which of the "nows"? The external or the internal? The intellectual or the emotional? The public or the private? These divisions and oppositions are, of course, largely fictitious. What finally makes what one is, what determines one's attitudes, one's predilections, one's outlook on life, and one's beliefs is no doubt the result of both external and internal, intellectual and emotional, public and private factors - influences and events that are extremely hard to capture in any order or chronology.

As I believe you know by now, I have always fought for the right to remain what Auden, in one of his poems, terms "a private face in a private place." The ways in which this simple wish was frustrated, and the circumstances at play there, constitute the subject of these fragments of a life... 
Please note that Arabic names, when transliterated, can be spelled a variety of different ways. The same individual's name may be spelled one way in the foreword and another way in the main text.

\section{$* * *$}

Throughout the many years the writing of these memoirs took, I drew on the knowledge and experience of various relatives and friends. My thanks to all of them. Special thanks are due to my dear wife Rachel, for her understanding and support through thick and thin. My thanks too to the directors and staff of the Harry S Truman Institute for the Advancement of Peace for their hospitality and day-to-day assistance. 
THE LAST JEWS

IN BAGHDAD 
THIS PAGE INTENTIONALLY LEFT BLANK 